\title{
Brikama Jali Kunda: Griot of Yesterday and Today
}

\author{
Karim Sagna \\ Earlham College, \\ 801 National Road West, Richmond, Indiana, 47374-4095, USA
}

For citation: Karim Sagna. Brikama Jali Kunda: Griot of Yesterday and Today. Vestnik of Saint Petersburg University. Asian and African Studies, 2020, vol. 12, issue 1, pp. 113-122.

https://doi.org/10.21638/spbu13.2020.108

\begin{abstract}
Serving as educators, genealogists, historians, musicians, and storytellers, griots play a fundamental role in Mandinka society. Following Mandinka tradition, Jaliba Kouyaté (or simply Jaliba, as he is commonly known), the celebrated griot from Brikama who is at the center of this study, is a well-known guardian of Mandinka cultural heritage in Gambia and Senegal (Senegambia). This griot-composer who is also a kora virtuoso and the lead vocalist for his Koumaré Band, shines not only within the music scene in Senegambia, but also in other influential Mandinka areas such as Guinea Bissau. Since the 1980s his art has stood out due to its combination of classic and contemporary kora, the Mandinka twenty-one string harp-lute, and its emphasis on the education and awakening of consciousness of Senegambians. Whether with noble genres or their reinvention in various musical forms, Jaliba Kouyaté continues to renew the art of the Mandinka griot without losing sight of his primary mission: to contribute to the enhancement of the individual and collective development of Senegambians who are his patrons, or jatiyo. This paper explores jaliya - the art of griot - in the work of Jaliba. In addition to examining the directions and techniques of his music and his use of musical poetry and dialogue to describe contemporary events, it analyzes his capacity to create worlds that reconstruct the Mandinka culture and civilization and to evoke through his kora new pages of Mandinka history.
\end{abstract}

Keywords: Mandinka, Senegambia, griot, oral tradition.

This study focuses on the topic of the art of the griot, or jali, an individual in Mandinka society who is entrusted with the memorization, recitation, and passing on of oral history from one generation to the next and who belongs to any one of a limited number of families. To speak of the griot is also to speak of what it means to belong to a class and an identity expressed through what Cherif Keïta has referred to as "the status of a man of particular class wherein the griot's most important artistic activity in Mandinka society is located" [1, p.15]. This extraordinary man and his work have long participated in the construction of the Mandinka people, for whom oral traditions generally reveal griot names linked to daily, historic events. For example, Gnankouman Doua and his son Balla Fasséké Kouyaté are griots who worked for and then passed on the histories of Naré Maghan Konaté and Maghan Sunjata, who were kings of the Mande Empire in the thirteenth century. These griots, also called "people of the word", transmitted various facets of Mandinka civilizations by word of mouth from father to son across the generations. They can be found everywhere within the vast territory of the Mandinka - which covers land in Mali, Côte d'Ivoire, Senegal, Gambia, Guinea, and Guinea Bissau. Here I will focus on the

(C) Санкт-Петербургский государственный университет, 2020 
Mandinka region of the Senegambia that I know best, a region located between northern and southern Senegal on the waterways of Casamance and Gambia. This region is filled with traditionalists and eminent griots whose artistic class creation has yet to be explored. These include griots of international renown such as Soundioulou Cissoko, Lalo Kéba Dramé, Al Haji Babou Diabaté, Sidiki Diabaté, Djélimady Cissoko, Aboulaye Sousso, and Bounka Susso, to name just a few. Since the 1980s, a new wave of griots has emerged in Senegal and Gambia. Jaliba Kouyaté (henceforth Jaliba), the focus of this study, is part of this new generation that orients its activities in innovative directions while maintaining the ways and class beliefs of the masters of the word. Here I will focus on the art of Jaliba Kouyaté, his trajectory as a griot, and his artistic initiation, with the aim of analyzing recurring themes in his work. I will also explore at length how he mixes different musical rhythms from the Mandinka zone of influence with the tones of his instrument of choice, the kora.

Jaliba Kouyaté (figure) is a Gambian griot from the city of Brikama, where he lives with his family. Originally from Niamina Dankunku, Jaliba earned a degree in teaching from Gambia College and worked as a teacher for five years before taking up his kora again and reconnecting with the griot tradition of his family. As his family name, Kouyaté, indicates, he is griot by birth and comes from a long line of griots. The Kouyatés, like the Diabatés, Cissokos, or Sussos among many other griot families, form an integral part of the large family of caretakers of the collective Mandinka memory charged with preserving and promoting the immaterial cultural heritage.

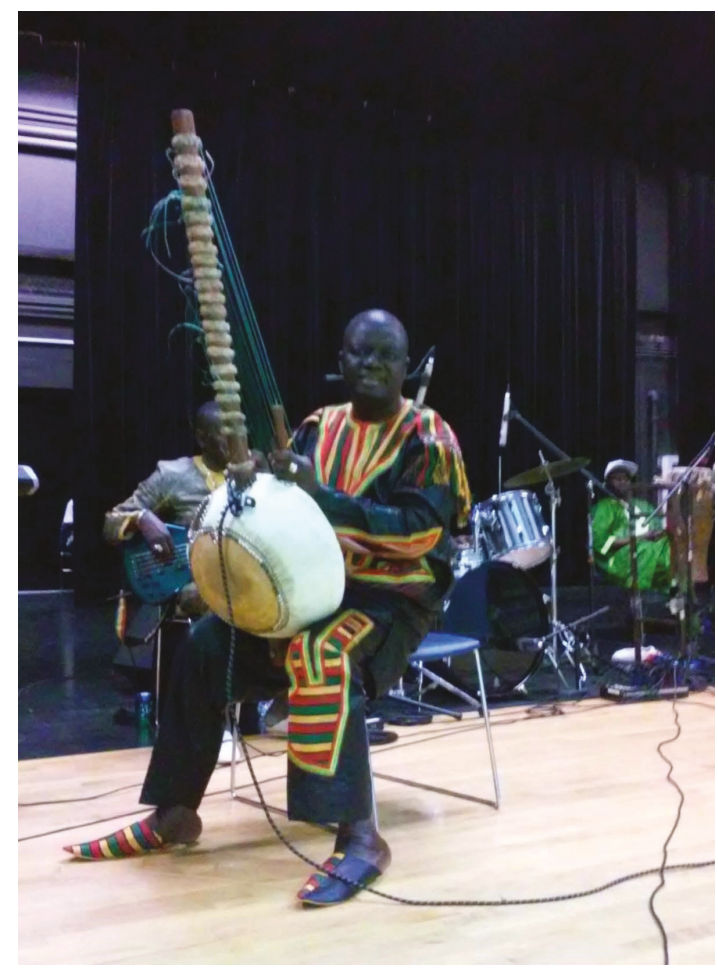

Figure. Jaliba Kouyaté in Cincinnati, Ohio

(photo is made by Karim Sagna, 2014) 
Djeli Mamadou Kouyaté reminds us of the griot's mission from the moment he begins speaking in Soundjata ou l'épopée mandingue:

I am a griot. I, Djeli Mamadou Kouyaté, son of Bintou Kouyaté and Djeli Kedian Kouyaté, master of the art of speaking. From time immemorial the Kouyatés have served the Kéita princes of the Manding: we are like sacks of words, we are the sacks that enclose secrets from the past of the past of the past. The Art of the word holds no secret from us; without us the names of kings would fall into oblivion, we are the memory of men; through the word we give life to the events and acts of kings for the young generations. [2, p.9]

Just like Djeli Mamadou Kouyaté from Djibril Tamisr Niane, griot and kora virtuoso Tumani Jabate returns to these terms when speaking of the role of the griot as witness and historian, repository of social memory:

I am a griot, and like all those of my lineage, I have the heavy duty of transmitting to my generation the wisdom taught by our grandparents, the virtues that characterized our ancestors, and the brotherhood ordained by our most ancient customs. [3, p. 253]

Here it is not the griot who wants to be a griot; the family name ties him to his caste, guides his life, and offers a model for action. Jaliba Kouyaté, who also belongs to this cycle of griots reproduced through their family heritage, is duty-bound to preserve and fulfill the charge entrusted him, and willingly to protect what Massa Makan Diabaté has called "the bond between those of yesterday and of today." In this vein, in Salif Keïta: L'ambassadeur de la musique du Mali, Chérif Keïta has emphasized that

the family name or jamu is the point of contact with the social personality of the individual; moreover it is known that each family name is associated with one or more emblematic symbols that serve as titles of honor allowing the individual to find his way in his daily life. $[4$, p. 43]

Here we see that the family name seals a pact and even a bond between those of today and of yesterday, as is illustrated in Malinke by the family name "Kouyaté" [ko yan tè], which means, "There is a secret, a pact, between us."

To better understand the griot's important social role, let's consider how Jaliba participates in this future-oriented discourse carried by the Kouyatés and other griots, or how he safeguards his family heritage and defends the social category of griots.

As might be expected, because it's the norm in a griot family, or in jali kunda, the initiation into the art of the griot necessarily passes through the teaching he receives within his own family. Jaliba is no exception to this rule because his biological father took it upon himself to give him this teaching and the indispensable tools for successfully fulfilling his duties as a griot. His initiation was de rigueur, in line with the expectations of a father who insisted on instilling in him the griot mentality and memory and on honing in him the power of the word while giving him an all-encompassing passion for his art. During this time, as he confirmed during an interview with me at his home in Brikama in 2013, he became knowledgeable in Mandinka cultural specificities, including the values, rules of behavior required for group cohesion, and knowledge concerning all of society, relations between persons, their milieu, and their ancestral past. This transmission of knowledge was organically reinforced through lessons on the kora and in singing to perfect his voice, for the griot is also a sworn musician-instrumentalist. Since the art of the word is an indispensable prerequisite for any griot, the griot's art was also inevitably exposed to all 
kinds of oratory methods so as to better accompany his kora music: he learned mnemonic laws and constructions and of course idiomatic expressions established over time as in, for example:

a ye dunia siti

he dressed himself in the best finery in the world

a ye dunia пaañaa

he paraded through the world

a ye dunia domo

he took full enjoyment in the world

a ye dunia taa man taa man

he wandered throughout the world

mu na

please

mo tan te dunia ti

the world belongs to no one fo tu ma

when the final count is taken

ben tu ma

when people reunite

mo tan te dunia ti

the world belongs to no one

dunia mu naane su ti

the world is a walled family compound

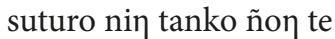

the safety and blessings are unequaled

ñin dunia bạ lun taa la

this world has no last day

These time-tested formulae function as refrains announcing and connecting different parts of songs that the griot artists would manipulate at will in his future repertoire.

As noted above, the griot is also a sworn musician-instrumentalist. He is inseparable from his kora, his chosen instrument. Also on this front, the griot's family demands a certain attitude of apprenticeship so as to gain access to the privileged circle of griots in the true sense of the term. The heart of this apprenticeship involves memorizing the rich repertoire of the elders, and the young griot is required to know to the letter the traditional musical tunes, with strict respect for their canonical rules. Ousmane Sow Huchard spells out several characteristics of these rules:

The repertoire based on the Cora is rich. The first motif that a griot instrumentalist learns to play is Kelefaba or the great Kelefa, a formidable Mandinka warrior. There is also the Douga, the Soundiata, the Soumaoro, the Boleoba or great motif played for famous men and tunes for all the ancient kings of Mali. [3, p. 260]

This rich repertoire that each griot must learn is called silaba, which means "the great road" in Mandinka: silaba delineates the road of the griot and serves as a starting point for his music. But it also places the griot in the wake of his elders, and this emblematic griot repertoire allows him to develop other motifs and songs to expand his musical horizons.

Armed with all this influence of both Mandinka cultural knowledge and music, Jaliba, who is able to take on with brio the repertoire of the silaba as well as the classics of the oral Senegambian heritage, believes that a true griot must not limit himself to playing and replaying the tunes composed by those who went before. According to him, that would of course be a curse! Rather, he holds that he owes it to himself to find a musical path of his own, and to give his art a unique style. Seen from this angle, Jaliba is in perfect agreement 
with the idea of the silaba as providing basic artistic fundamentals and as placing the onus on the griot to open his art to other musical horizons. His attitude toward the silaba is in line with the ideology of self-transcendence encouraged by Mandinka culture, where fostering constant change is a hymn celebrating individuality within the aesthetic space of griot art. This attitude is exactly what Jaliba put in place in the 1980s when he formed Kumaare Band, the Crowned Crane in Mandinka, where the crane is a bird known for the beauty of its plumage and the elegance of its voice, just as Jaliba is known for the beauty of his texts and his voice. He seduces all with his words and his musical chords. During the

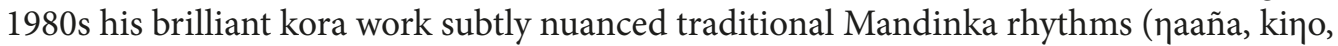
sewurba, jembe, lenjeno...) with the tones of jazz, Afro beat, Afro-Cuban music, rhythm and blues, and even techno.

With the help of the Kumaare Band, Jaliba participated in modernizing the kora in Senegambia, a change that several factors imposed on his musical space. In terms of commercial profit, the griot earns his living thanks to jatigi, or patrons; but since those on whom the life of each griot's family depended scarcely exist anymore, the griot must find new patrons who are unfortunately more drawn to modern music than to the kora with its tunes of yesteryear - noble genres such as epics and other forms relating the important deeds of the grand patron families [5, p.598]. Being of his era and able to take advantage of it, Jaliba reconceived his art so as to recapture his audience; he quickly internalized the adage, "Whoever wants to live, whoever wants to remain himself, must compromise" [2, p.20]. He began negotiating his music in line with the rules of the art of the griot, maintaining the personality as specific to a griot while committing to the reinvention of diverse aspects of Senegambian daily life through a lively, uplifting music with the frenzied rhythms of Afro-Cuban music, rhythm and blues, or simply old, well-known tunes dug up from the depths of traditional Senegambian music.

As a good griot committed to his mission, Jaliba performs griot art while serving an ideal that has as a primary objective the individual and collective wellbeing of Senegambians, something he himself confirms in the song "Wassa" by reminding us in passing of his role as popular educator:

dunia mbe ku kendool noma

dunia I commit to the just cause

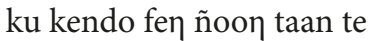

the just cause is unequalled jon te ñinala

none will forget

al na karan di daajiko ñinma

let's teach it good manners

Here, Jaliba is the "griot builder of the nations" whose class-based efforts work for the betterment of the person who is always at the center of his artistic creation: "al na karan di daajiko ñinma". Jutaala Konté, another griot who granted me a long interview in June 2013 in Bignona (Casamance, Sénégal), believes that the foundation of griot art rests primarily on the idea that the griot is a "builder of nations", or jali dadaarla in Mandinka. The verb dadaarlo means "to repair" and dadaarla means the "reparer". Jali Jutaala Konté states that the most important class effort of any griot must contribute to creating or maintaining a thriving world, and that any griot art opposing the idea of dadaarlo no longer qualifies as such. From this point of view, it is clear that in Wassa, Jaliba places himself 
within the dynamic of the jali dadaarla, a function he continuously stresses in his illustrious repertoire as he does so brilliantly in the rest of this same song by taking inspiration from the famous traditional Mandinka rhythm jambadon, or dance of the leaves, to pay homage to women and to advocate their involvement in state leadership activities and in politics in general:

musolu woo musolu wo musolu wo oh women oh women oh women

gambia musolu al nee sinbe turyandi

Let's give power to the women of Gambia

musolu woo musolu wu musolu wo

oh women oh women oh women

senegambia musolu woo al nee sinbe turyandi

Let's give power to the women of Senegambia

duniya woo musolu mbaalima

oh women of the world I'm speaking to you

musolu be kunko to

women are in the fields

dool be nakoo to

others are in the kitchen gardens

musol be farooto dool be lo ñinola

women are in the rice fields others gather wood

musol be din baa yaala

women raise children

xaani dool be ndawal bondola

while others take care of daily expenses

al nee sinbe turyandi

Let's give them power kabirin 1980 musol la kafo loota

Since 1980 the organization of women has existed

sanji muwon nin fuulu xaanibi abe barkarin that's 25 years of our time that it's been in operation

muso kupmalu tonbontale gambia ani mansakunda ka musolu sinbe turyandi women leaders are elected in Gambia and the government gives power to women

dunia

people of the world

musolu woo mbaalima

oh women I'm speaking to you

nee sinbe turyandi

let's give them power

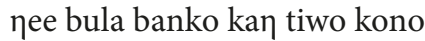

let's integrate them with the leaders of the earth

musolu woo musolu wu musolu wo

oh women oh women oh women

banko musolu woo al nee sinbe turyandi oh women of the world let's give them power

The ideology of the dadaarlo can be traced throughout Jaliba's music. In another famous song, he speaks to the idea that the value of any individual depends on his contribution to the affairs of his community. These are the obligations about which he reminds his patron, Saikou Jammeh of Badibou, who at one point rewarded him with honor and material goods. He reminds him of three behaviors that must permeate each person's life:

ye mu ne ki jan what did you do here? ye mu ne fo jan

what did you say here? ye mu ne tu jan what did you leave here? 
We realize that the word and the deed, which are the key elements of this excerpt by Jaliba continually engage the individual and follow him always and everywhere in his life, and furthermore, engrave themselves in collective memory for posterity. The simple fact of reminding Saikou Jammeh of this wins him over to Jabilya's positions even as it encourages him to defend and continue the honorable actions worthy of a Jammeh. This song, which offers a straightforward combination of Mandinka ballad and Afro-Cuban salsa rhythms, illustrates clearly that Jaliba is a skilled artist of the word who knows how to impress through elegance, depth of discourse, and music. He never sings without saying something, and listening to him means going back in time as in the case of Moriya, which was composed with the currently trendy Wolof mbalax tune, in which Jaliba evokes the rich heritage of Senegambian marabouts who intervene from near or far in the all stages of life. What do we do in Senegambia without consulting a marabout who, according to popular belief, has not only the power to help with present success and predict the future, but also to guarantee success with his prayers? Jaliba pays tribute to these marabouts who, as heard in the praises he showers on them, directly intervened in his life and helped him become the griot he is today. He praises them at every opportunity and helps save their names from death and oblivion. Jaliba expresses his gratitude to them and underscores the mystical power of their spiritual work that relies on prayers.

moriya moriya

Islamic knowledge Islamic knowledge

cosaan kama

for tradition

fo dool ye moriya

others must be marabouts moriya dan mu min te

the final goal of Islamic knowledge

fo duwa jaabi

is the materialization of prayers

afan suley mu mori baa le ti

afan souley is a great marabout

Jaliba is a griot who fits perfectly in his era because his music often resonates with current events that he likes to look back on with pleasure and passion, always keeping in mind the dynamic of the jali dadaarla as the credo of his art. Faced with the fact that Senegambian youth wallow in comfort, idleness, and other evils that continually undermine them, Jaliba invites them to take their destiny in hand and above all to follow role models provided by those around them:

fonding keelu aal nan kalan kendool dammalula

youth, let's imitate only the best [from among us]

At the same time, he raises his voice to lead awareness campaigns against AIDS which, for him, is the plague of the century come to decimate the populations:

sayaa sayaa

death death

sayaa ñaך ta moo silaך na

death must bring fear mbee le yaa mooy kuranba le funtitaa

we have all heard that a great sickness has appeared

aw jubilla aids naa ta turbano le la

aw jubilla AIDS came to decimate the populations 
Here we are dealing with an educator and awareness raiser who takes the campaign against AIDS very seriously. He addresses a broad audience without letting anyone off the hook. From young people proud of their sexual meandering to whom he says without flinching, "xada di bi / jusu jaaba ye ke titaroli" [today / the stubbornness of men has become an [unfortunate] pride], to women who perform genital mutilation and tattoo artists, Jaliba attacks social practices that often endanger equally-sacred individual lives: " " a sila saaya la" - "let's fear death". Human rights, AIDS, malaria, alcoholism, illegal immigration, violence against women, ethnic conflicts: Jaliba addresses them all. His piece fitinaa, built on reggae rhythms, is a beautiful example:

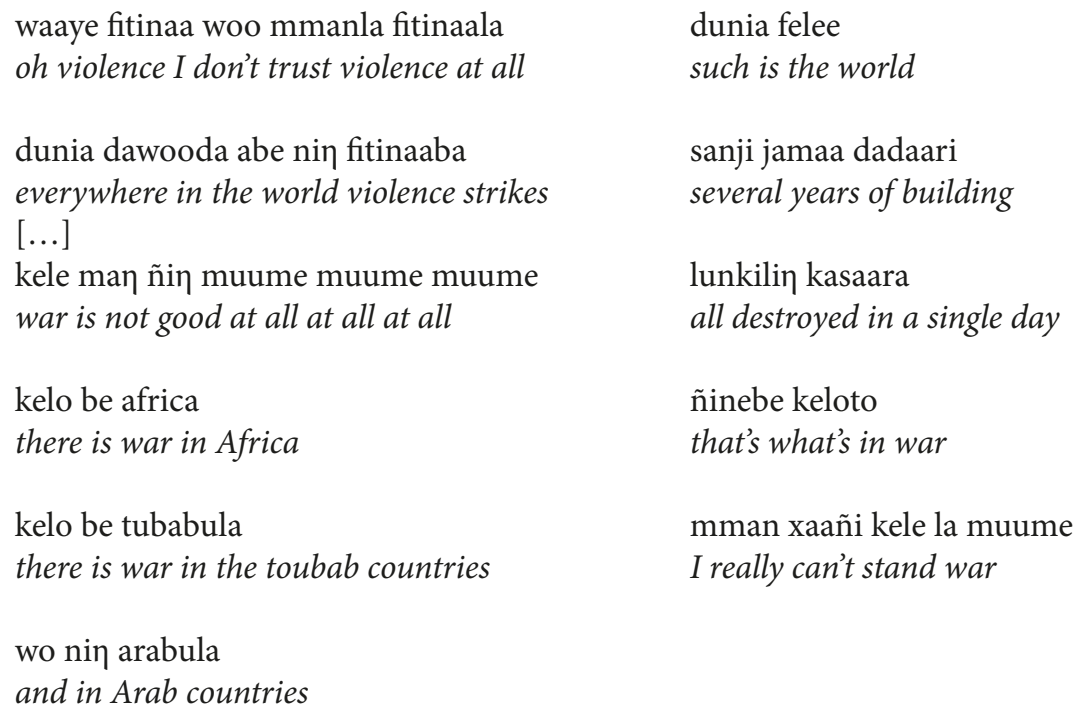

Sometimes Jaliba switches universes in his musical imaginary and addresses homemakers with entertaining images as in the case of the piece dedicated to Sankoung Sylla:

kuur la ni be koyoo le ñinin

laundry woman if you're looking for the whiteness of your clothes

sankun na safino ye la fenol kooy imaa fet feti

the Sankoung soap whitens your clothes without scrubbing fet feti

imaa fet feti

without scrubbing fet feti

ye la fenol kooy imaa fet feti

you whiten your clothes without scrubbing fet feti

sankuך la dadaaro moo te ñinala Africa

none shall forget the work of Sankoung in Africa 
As in the above example, Jaliba knows how to make unexpected blends. This song

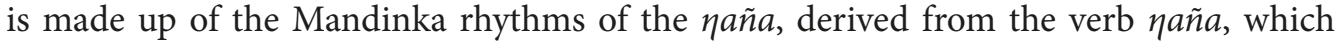
means "to boast" or "to show off". This traditional dance features a very slow swaying of the chest and legs - an opportune moment for the dancers to flaunt themselves in all their glory and savoir-faire on the dance floor. The link between Sankoung Sylla, the great salesman of Brikama, and the homemaker is impressive. The aesthetic and musical space of the $\eta a \tilde{n} a$ allows Jaliba to bring new vigor to this ancient, lilting Mandinka tune. To this commercial-style song adds the hallmark specific to the chronicler and catalyst of the people whose "key psychological function consists of unleashing emotions, liberating affective forces" [3, p. 394]. He therefore invites an imitation of Sankoung Sylla's action on behalf of people's individual and collective wellbeing. In so doing, Jaliba promotes the old traditional Mandinka tunes such as the naña - rhythms threatened by oblivion in the Mandinka cultural space of Senegambia.

By occupying the place handed down to him, that of dadaarla and of awareness raiser, Jaliba is of the same cut as the leading lights of griot art in the Mandinka cultural space. Like them, he tirelessly guards against artistic mediocrity, since for him, the griot's music is always destined to rise to the challenges imposed on him by the ideology of the silaba and of dadaarlo. His artistic initiation leaves no place for improvisation or guesswork: all is carefully measured in music that he unerringly sings with the right words for narrating his universe. He knew how to place himself in the lineage of the "people of the word," and I would go so far as to say that Jaliba is of the same mold as artists such as Salif Keïta, Tiken Jah Fakoly or Tumani Jabate who know how to produce the Mandinka musical heritage with great skill. In this respect, Jaliba deserves his last name "Kouyaté" as well as his first name, Jali-ba, which is doubled with the augmentative and ameliorative suffix "ba" and refers to the "great jali" he is today and the fact that he serves as a key artistic model in Senegal and Gambia.

\section{References}

1. Cheick M. Chérif Keïta. Salif Keïta: Loiseau sur le fromager. Bamako, Le Figuier, 2001. 15 p.

2. Djibril Tamsir Niane. Soundjata ou l’épopée mandingue. Paris, Présence Africaine, 1960. 9 p.

3. Ousmane Sow Huchard. La Kora: Objet-témoin de la civilisation manding (essai danalyse organologique d'une harpe-luth africaine). Dakar, Presses Universitaires, 2000. 253 p.

4. Jacquey Marie-Clotilde. Être griot aujourd'hui: Entretien avec Massa Makan Diabaté. Littérature malienne. Notre Librairie, 1989, pp. 115-119.

5. Drissa Diakité. Kuyatè, la force du serment: aux origines du griot mandingue. Paris, L'Harmattan, 2009. $26 \mathrm{p}$.

Author's information:

Karim Sagna — PhD; sagnaka@earlham.edu 


\section{Джали Кунда из Брикамы - гриот прошлого и настоящего}

\section{Карим Сагна}

Колледж Эрлхама,

США, Индиана, 47374-4095, Ричмонд, Западная национальная дорога, 801

Для цитирования: Karim Sagna. Brikama Jali Kunda: Griot of Yesterday and Today // Вестник Санкт-Петербургского университета. Востоковедение и африканистика. 2020. Т.12. Вып.1. C. 113-122. https://doi.org/10.21638/spbu13.2020.108

Данная статья посвящена музыкальному искусству и поэтическому творчеству гриота Джалибы Куяте, знаменитого гриота из Брикамы, одного из самых важных персонажей в сенегамбийской музыкальной культуре. Гриоты играют очень важную роль в обществе мандинка, будучи для своих соотечественников как хранителями истории, музыкантами, рассказчиками, так и учителями. В традиции мандинка Джалиба Куяте, или просто Джалиба, чье имя переводится как «большой гриот», известен как хранитель культурного наследия своего народа в Гамбии и Сенегале (Сенегамбии). Гриот-композитор, который является и виртуозом в игре на коре и ведущим вокалистом в своей группе Кумарэ, блистает не только на сцене в Сенегамбии, но и в других районах, где проживают мандинка, таких как Гвинея-Бисау. С 1980-х годов его искусство отличалось как сочетанием традиции и современности в игре на коре, 21-струнном инструменте, так и самой направленностью его творчества на воспитание и пробуждение сознания сенегамбийцев. Будь то благородные жанры или другие музыкальные формы, Джалиба Куяте продолжает развивать и обогащать искусство гриотов мандинка, не отходя от своей основной миссии: способствовать дальнейшему развитию сенегамбийцев, которые являются его патронами, или јаtiуo. Данная статья посвящена не только изучению его музыкальной техники, но и использованию им гриотской поэзии для описания современных событий. Мы обращаем внимание на его умение создавать миры, воссоздающие культуру и цивилизацию мандинка, а также способность творить современную историю общества мандинка при помощи своих произведений и игры на коре.

Ключевые слова: мандинка, Сенегамбия, гриот, устная традиция.

Статья поступила в редакцию 14 января 2019 г., рекомендована к печати 12 декабря 2019 г.

Контактная информация:

Карим Сагна - PhD; sagnaka@earlham.edu 